December 2015

\title{
Still Glowing Strong: Review (Denmark)
}

Anna Elisabeth Jessen

Follow this and additional works at: http://ro.uow.edu.au/rdr

Part of the Audio Arts and Acoustics Commons, Digital Humanities Commons, $\underline{\text { Radio }}$ Commons, and the Scandinavian Studies Commons

\section{Recommended Citation}

Jessen, Anna Elisabeth, Still Glowing Strong: Review (Denmark), RadioDoc Review, 2(2), 2015. doi:10.14453/rdr.v2i2.1

Research Online is the open access institutional repository for the University of Wollongong. For further information contact the UOW Library: research-pubs@uow.edu.au 


\title{
Still Glowing Strong: Review (Denmark)
}

\begin{abstract}
Still Glowing Strong is Norwegian Sindre Leganger's tender story of an old man, Harald, who thinks he has invented an everlasting battery that could save the world. The problem is that no one has the time to look at it - his wife in particular. But as Leganger and the old man's grandson take an interest, this short but remarkable feature reveals much about our finite lives and the eternal starry sky above us, about being stubborn, being optimistic and about hope. Leganger illustrates Zola's dictum, that "art is a corner of reality seen through a temperament". He plays three roles: Narrator, as we hear it mixed from the studio in the feature; Reporter as we hear Sindre asking his questions and commenting in Harald's home; and Author. The author is not heard; the author is the person composing by editing. Enjoy the language, the story, and the composition.

NRK (Norwegian Radio) is known for technically well produced features where you can hear that time has been used in the studio for the finest editing, the best recordings of narration and an elegant mix. This feature is so well produced that it is very easy to listen to. But the strength of the feature is its clear focus, this "corner of reality", as Zola puts it. We as the listeners stay with Harald and his project all the way; we follow him, his wife Borghild, and the grandson, to the testing of the everlasting battery. After hearing this feature, we as listeners, are touched by its quiet strength.
\end{abstract}

\section{Keywords}

radio documentary, audio feature, Norway 


\title{
STILL GLOWING STRONG
}

\section{Review by Anna Elisabeth (Lisbeth) Jessen}

\author{
A radio feature by Sindre Leganger \\ Technical direction: Erki Halvorsen \\ Consultant: Kari Hesthamar \\ Date of first broadcast: NRK April 26 ${ }^{\text {th }}, 2014$ \\ Duration: 24 '42
}

Throughout his 86 years of life, Norwegian Harald Brobakken has looked up at the starry sky and wondered if there is energy up there that could be used for something. When he was 80 years old, he made his great discovery. In the study of his small flat in a satellite town of Oslo, Harald has created what he believes is an everlasting battery - an invention that perhaps could save the world. The problem is that no one has the time to look at it - his wife in particular.

With support from his grandson, Harald wants to get scientific corroboration for his invention.

The program maker Sindre Leganger went to visit Harald and his wife several times in their flat, to look at the everlasting battery and talk about how it works. He is also there when a scientist from Oslo University comes to check out the invention.

Apart from following the concrete aspects of the story, most of all, this is a program about our short lives and the eternal starry sky above us, about being stubborn, optimistic and about hope.

When listeners ask me what is a radio feature - a good radio feature $-a$ radio feature that you will not soon forget, or when radio feature makers ask the same question, I often quote the French novelist, critic and political activist Emile Zola (1840 - 1902), who in his theories of naturalism explains art thus: "Art is a corner of reality seen through a temperament."

Clear isn't it? When it comes to radio feature making, we are dealing with reality - not fiction - but we try to create some kind of art out of 
composing our story. We do that by having a clear angle or focus on our material as we compose it through our "temperament."

I find that Still Glowing Strong, this rather short but remarkable feature made by Norwegian Sindre Leganger in 2014, fits well into old Emile Zola's description.

The author Sindre Leganger is young, he hasn't made many features yet, and this story just landed on his desk as an email when he worked for NRK's feature department. At first he did not believe the story because the email mostly talked about technical stuff, but after visiting, talking to and recording Harald, he realized that there was something more in this story than just a feature about a possible invention.

However, Sindre and his NRK editor had doubts about Harald's voice. Did he speak clearly enough? Cancer had hit his tongue. Harald, the protagonist, was old and sick. But what struck Sindre most at the first meeting was the vitality, but also tension, between wife and husband in the small flat.

Still the story needed more. Very important in this feature is the narrator, the poetic narrator, who of course also is the author, Sindre Leganger. With this narration in a young man's voice combined with the voice of Harald, the old man, another layer, something bigger was born.

The audience at the Prix Europa in 2014 could hear that; they gave Still Glowing Strong a Special Commendation.

Here we have an extremely focused story about an old man who has a project. He wants to invent an everlasting battery, and he thinks he has already done it.

Harald himself explains it in this way - here translated from Norwegian:

“This is an everlasting battery. There are billions of people who don't have access to electrical power, but now can get it. If this is confirmed I will claim this is the greatest invention ever made in the history of humankind - if I'm right? That's why a physicist has to look into it." 
But the test has not yet been made when Sindre meets Harald, so Sindre becomes a helper in the feature. Like in the old fairy tales where a man has a project, and to fulfill it in the fairy tale he gets a helper, but also an enemy. When French structuralist Julien Greimas analysed old fairy tales he talked about the actantial model. A prince wants to marry the princess; the prince has a helper and an enemy. This is the way good stories are always told. Here in the feature about the old inventor, we can use this model to describe how the storytelling works.

Sindre describes Harald, our protagonist in his poetic narration - here translated from Norwegian:

"A skinny man sits stooped over a workbench in his room. In front of him there are tools, wires, small plastic boxes with a grey soup consisting of miscellaneous elements. All of them coupled to a light that never goes out."

Harald's wife is not completely the enemy, the antagonist, but she is clearly against Harald's project. She is sceptical, his surroundings are also rather sceptical, but Harald has someone who believes in him, his grandchild. Every week this other helper according to Greimas' model, Kjetil, the grandchild comes by. He is 20 years old, the youngest of four grandchildren. He is the only one in the family who supports Harald in his belief in his invention.

So we have two helpers on the stage, the grandson and the author, Sindre Leganger. It is Sindre who ensures that Harald's invention is going to be tested. Does the everlasting battery function or not? Why has it taken so long? Why have so many years passed by?

Another obstacle - another enemy you would say, is time.

The narrator:

"He is 86 years. Half of them he spent in the postal system. Always with a book on physics in his back pocket. A letter going here, a package going there, but Harald had other things on his mind. As an old-age pensioner he could realise his dream. The invention that may save the world. But Harald doesn't have much time. Perhaps only one year left to live." 
Perhaps the biggest obstacle or enemy is time. Harald is not only old, he is also sick from mouth cancer.

NRK is known for technically well produced features where you can hear that time has been used in the studio for the finest editing, the best recordings of narration and an elegant mix. This feature is so well produced that it is very easy to listen to.

But the strength of the feature is its clear focus, this "corner of reality," as Emile Zola puts it. We as the listeners stay with Harald and his project all the way; we follow him, his wife Borghild, and the grandson, to the testing of the everlasting battery.

You could say we are in a very small universe, but it is a delicate one, and Sindre Leganger develops it with his artistic temperament through a fine narration.

The narration is quiet and well read, close to the microphone, so that acoustically the narration brings another layer into the feature.

Here again is a poetic quotation from Sindre Leganger:

"Twilight in Tveita. The stars are vaguely seen as tiny dots in the night sky. The blocks of flats are quiet and dark. In one window though, there is light. Faint, barely visible, but still a constant light. Night and day."

The narrator is the same person as the reporter. Together the narrator and the reporter become the author. So you will find three roles for Sindre Leganger: Narrator as we hear it mixed from the studio in the feature; Reporter as we hear Sindre asking his questions and commenting in Harald's home; and Author. The author is not heard; the author is the person composing by editing.

When Sindre Leganger as reporter is heard he is not so close to the microphone, Sindre as narrator is much closer.

The author and narrator Sindre Leganger of course knows everything, because the narration is made after the recordings. The reporter knows less. He learns things together with us, the listeners. 
In the beginning of the feature when we are presented with this old man's project, we are probably sceptical, like Sindre was at first.

Harald says:

"Cosmos, right. Call it "dark energy." It's out there, force fields we don't see, that are not being made use of. That's why I think this is a great invention. That's why I haven't given up. I'm really quite sure it comes from space. Who would think that it's this cheap to make a power plant? No one imagines the possibility. But I have the proof here and that's why I want a physicist to disprove - or confirm."

Is this man just old and crazy you might think? But then the feature has a turning point. Sindre Leganger helps Harald to make real contact with the world outside his flat to have his everlasting battery tested.

Suddenly something completely new and unforeseen happens. Ola Nielsen, a chemist from the university, comes to Harald's flat to test his invention:

"Telephone call:

OLA NILSEN: (on the phone) Ola Nilsen.

JOURNALIST: (on the phone) I'm calling about a Mr Harald Brobakken who is an 86-years-old man living in Tveita.

OLA NILSEN: In Tveita? That's quite close to where I'm situated. Well, I do know a few things about batteries, I would say.

JOURNALIST: If you are close to Tveita, would you mind dropping by one day and take a look at it?"

Now as listeners we become completely impatient to hear the verdict. Suspense is built up. At first Ola Nielsen the chemist is very impressed by the old man's work, but in the end he has to disappoint Harald with his verdict:

"OLA NILSEN: Yes, where does it go? At least it happens through the plate, through your system. So one place or another you have a conductor that 
runs through this. It means that the humidity around these containers of yours is so high it conducts the ampere necessary. Because this is a cell. You have created a cell. I think your answer lies there."

Ola Nielsen concludes that instead of an everlasting battery, Harald has made an ordinary battery.

Is this then the end of the drama? No, not at all. We also have an elegant epilogue, because Harald does not give up. Two days after the visit, an email from Harald arrives to the reporter Sindre.

“Hello Sindre. I just want to tell you I didn't agree with the explanation the chemist presented. Among other things, he said it was humidity that transferred electricity from the battery to the lamps. I have known about the humidity for a long time and I believe I have solved that problem. I'd like to hear an expert give an explanation of how this can take place and I welcome the chemist back again."

So there is hope. Harald does not give up.

After hearing this feature - we, as listeners, are touched by its quiet strength.

So please listen to the whole feature and take a trip to a block in Tveita in Norway. Enjoy the language, the story, and the composition.

Enjoy the corner of reality told by a Norwegian temperament.

Harald, though, gets the last words:

"I would really like to find an explanation of why the lamps are still glowing you know. When I can prove there is no connection between plus and minus the power must come from elsewhere. And the only place that could be is the cosmos."

AUDIO of Still Glowing Strong is HERE. https://soundcloud.com/radiodocreview/still-glowing-strong

English transcript is posted as a pdf with review abstract and below. 


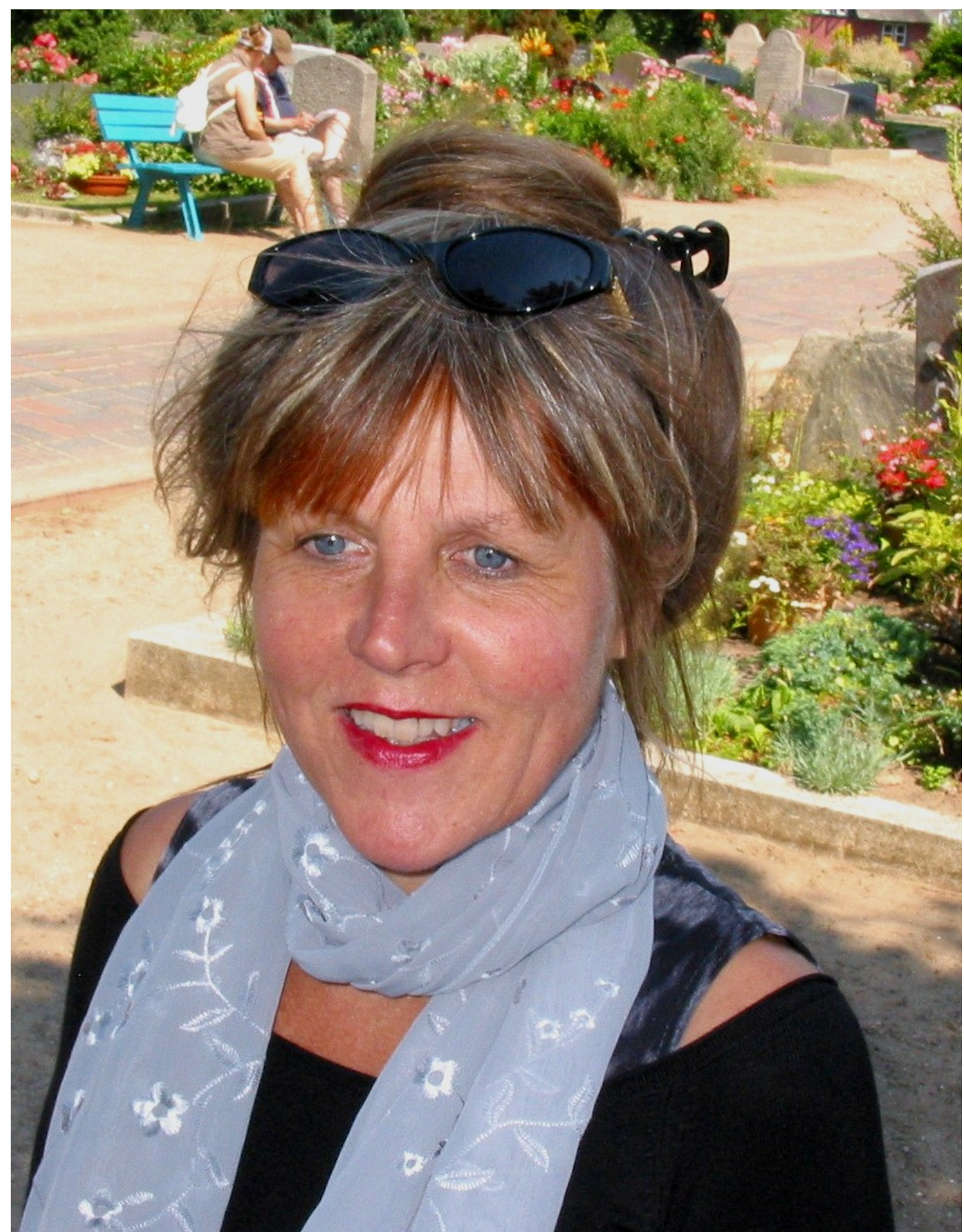

Anna Elisabeth (Lisbeth) Jessen is a graduate of the University of Copenhagen, the Danish School of Journalism and the National Film School of Denmark. She has produced features in various genres, from the classical Danish style to programs carried by investigative journalism. Anna Elisabeth won the Prix Italia in 1988 with Why didn't she ring back? and again in 2003 with After the Celebration, which received a Special Commendation at the Prix Europa the same year. In 2006 she received a Special Commendation at the Prix Italia for Doctor Tramsen's Report. She has also jointly won national prizes with the Danish Radio Documentary Group. For the last 10 years, Anna Elisabeth has made radio features, television features and documentary films. From 2004 to 2014, she coached emerging talents at the European Broadcasting Union (EBU) International Training Master School. Some of her works both for radio and TV have been aired internationally and adapted into other languages. Anna Elisabeth works as an independent author and director, based in Denmark and in Germany. 
STILL GLOWING STRONG

\author{
By: Sindre Leganger \\ Technical direction: Erki Halvorsen \\ Consultant: Kari Hesthamar
}

Duration: 24'42"

Music

NARRATOR: $\quad$ Twilight in Tveita. The stars are vaguely seen as tiny dots in the night sky. The blocks of flats are quiet and dark. In one window though, there is light. Faint, barely visible, but still a constant light.

Night and day.

HARALD:

The starry sky is really beautiful. When it's completely dark and there are no other lights - it's quite inconceivably beautiful.

NARRATOR: $\quad$ A skinny man sits stooped over a workbench in his room. In front of him there are tools, wires, small plastic boxes with a grey soup consisting of miscellaneous elements. All of them coupled to a light that never goes out.

HARALD: $\quad$ These here, these are plastic. And this I cut here. Like that. And then I pour this mass in there. Right. And then I have this power plant. 
NARRATOR:

He is 86 years. Half of them he spent in the postal system. Always with a book on physics in his back pocket.

HARALD:

I took off the hard cover to make it easier to carry in my pocket.

NARRATOR:

A letter going here, a package going there. Harald had other things on his mind. First as an old-age pensioner he could realise his dream. The invention that may save the world.

HARALD:

To me, this is an everlasting battery. There are billions of people who don't have access to electrical power, but now can get it. If this is confirmed I will claim this is the greatest invention ever made in the history of humankind - if I'm right. That's why a physicist has to look into it.

NARRATOR:

But Harald doesn't have much time. Perhaps only one year left to live.

HARALD:

I don't reckon I have more than one year left. So I hope it will happen before that. Because now I have mulled over... Since I was five years old I have pondered. Now I don't have the strength anymore. Now someone has to take over.

Music out

BORGHILD: "End it already" I say to him. (laughs) I do that, actually. I think it's nonsense, the whole ting. Maybe it's mean but I think there's so much mess with it. Nothing comes out of it. "Can't you just terminate it" I say "and like, just 
disconnect?" But no; it's no use. He thinks he's made a great invention, you know.

Me, I don't think so.

NARRATOR:

Borghild is 87 years old, quite exactly five months older than Harald. They met the fourth of July 1952, half past four in the afternoon. The stars were hidden behind a cloudy summer sky when the young nurse went to check Harald's ulcer. He made up his mind the moment he saw her.

HARALD: I immediately knew: "her or no one". After that I didn't even look at other girls. I wouldn't find anyone as good as her.

BORGHILD: $\quad$ I didn't notice him; it wasn't that kind of situation. There were a lot of lads laying there. I didn't think about Harald at all. But we have been doing fine. Can't say otherwise. Now he's ill, you know, so he's not very agile. And he's so skinny - 40 kilograms, you know; that's nothing. He used to read a great deal and played the guitar and sang - and was very alert and bright. But in later years he got tired and that's when he started with this thing. And it has sort of filled his whole life.

But it glows, and it has glowed all the time. It's kept going for a long time now.

Balcony door opens

BORGHILD: $\quad$ There's a good view from here but now the windows are so awful one nearly can't see out.

NARRATOR: $\quad$ They both have their own territory in the small flat. 
BORGHILD: (points from the balcony) That is Teisen.

NARRATOR: $\quad$ Harald in front of his workbench. Borghild in front of the tv in the living room. They meet on a glass-enclosed balcony with a view over the city.

BORGHILD: $\quad$ And then, here is...

HARALD: Alnabru.

BORGHILD: Yes, Alna is over there, of course.

NARRATOR: He smokes, she tidies.

A match is lit

HARALD: Right. This is a hearty smoke.

BORGHILD: $\quad$ That's quite a lot of smoke, you know.

HARALD: I only smoke on the veranda. Not in the living room. That way I think I show consideration towards those who are in the living room.

BORGHILD: $\quad$ Yes, but the smoke comes in.

HARALD: $\quad$ Well, that's what it doesn't.

BORGHILD: $\quad$ That's what I think, anyway. I notice it.

HARALD: Well, that's against the laws of physics. 
BORGHILD: $\quad$ (laughs) You and your laws.

HARALD: $\quad$ Heat always migrates to colder places.

BORGHILD: $\quad$ You never give in, pa.

HARALD: $\quad$ No, I don't give in.

Borghild laughs

HARALD: I'm so curious, you see. I've always been curious. Curious since I was five. Over-curious about everything that happened. I had to examine: Why? What? And how? Then I started gazing at the stars.

And that settled it.

Rummaging with matches

HARALD: When a battery can endure for several months, years, actually, people have to see that this is on a track that could lead to something very important for humankind.

JOURNALIST: $\quad$ But the energy has to come from somewhere?

HARALD: Yes, there you're getting at something. I am convinced that this comes from cosmos.

JOURNALIST: Cosmos?

HARALD: $\quad$ Cosmos, right. Call it "dark energy". It's out there, force fields we don't see, that are not being made use of. That's why I think this is a great invention. That's why I haven't 
given up. I'm really quite sure it comes from space. Who would think that it's this cheap to make a power plant? No one imagines the possibility. But I have the proof here.

JOURNALIST: What do people say when you tell them about this?

HARALD: They laugh at me. Laugh at me. Not a single one has supported me. And that's why I want a physicist to disprove - or confirm.

Music

Doorbell

Door opens

HARALD: Hello Kjetil! Welcome!

Door closes

KJETIL: $\quad$ How are you doing?

HARALD: Now it's going to be really nice to talk with you. Shall we look at the project?

KJETIL: $\quad$ Yes, we must.

NARRATOR: Every week Kjetil comes by. 20 years young, the youngest of four grandchildren. The only one who supports Harald in his belief in his invention.

KJETIL: Well, we have to clean your laboratory one of these days.

HARALD: Yes, you've promised to do that.

KJETIL: $\quad$ Mm. What are you doing here, then? 
BORGHILD: $\quad$ Kjetil takes his time with him and chats and helps him and seems interested. He listens. He comes here, you know, and sits and talks with Harald. They can sit for hours on the veranda and talk. I think that has meant a lot to him.

HARALD: Now it has shone - well, from the beginning of March.

KJETIL: $\quad$ Mm.

HARALD: $\quad$ And when it's dark and no other light is on, it's actually so bright you can read in it.

KJETIL: $\quad$ It's easy to view this as just a heap of junk. "Okay, there's a lightbulb that's shining but that doesn't prove anything." Therefore I think it's very important he gets a little support from someone. This might be some sort of trickery, in a way. But I believe he should get a chance, though. Everyone deserves a chance and be listened to. This has been the main reason for my positive attitude to his work; I can see he enjoys himself. I see he's having a damned good time when he's doing this. And that's worth a lot to me.

KJETIL: $\quad$ We'd better work a bit more with that. And then I have to shop those ingredients.

HARALD: Well, now I think I have to sit down.

KJETIL: $\quad$ Yes. Right. Have you been standing too long?

HARALD: Oao, that was nice. 
KJETIL:

Do you need anything? Coffee or...?

HARALD: Well, no.

KJETIL: I know very well he doesn't have much time left. He's had cancer in his tongue and I have actually waited for it to happen. The reason he's managed to keep alive I think is his tenaciousness and this project.

BORGHILD: I I I $\quad$ Idn't believe him when he said "I have a lump on my tongue, it's probably cancer". We often put things that way, you know. I didn't believe it. First, test samples were sent to the central hospital, where they said it was nothing. Then, he went to his dentist the week after and he said "Here there is danger afoot".

HARALD: $\quad$ Fourteen days later I was operated. That was May 20th last year.

BORGHILD: $\quad$ He has dealt with it quite well. He has some difficulties talking. He had started with this stuff before that, you know, but afterwards, this has kind of been the only thing on his mind.

KJETIL: $\quad$ I feel that the whole last part of his life, from he was 82 until now... I don't think he's going to die before he's had his wish fulfilled. I believe that's what keeps him alive. Tobacco and science. That's what it's all about.

\section{Music}

HARALD:

My dad had a job in the Postal services. He had a 
motorbike which he delivered the mail with.

NARRATOR: $\quad$ Harald grew up in Vestre Toten (Western Toten). His job in the Postal services was kind of a family tradition.

HARALD: $\quad$ But for some reason or other he got fired.

NARRATOR: $\quad$ They were eight brothers and sisters. The family started cultivating a patch above their house.

HARALD: $\quad$ We grew potatoes and we had five, six cows.

NARRATOR: $\quad$ Money was scarce. But in school Harald showed a talent for arithmetic.

HARALD: $\quad$ I didn't want to finish school because I enjoyed myself so much. I went an extra year in primary school just because I wanted to go to school. My parents didn't have the money to send me to lower secondary school, though. So that was the only education I got.

NARRATOR: $\quad$ He came to Oslo a year after the war, with his rucksack full of worn books on scientific subject and without enough money to get along.

HARALD: $\quad$ So I just went to the post office and asked if they had a job vacant. "Yes, you can start tomorrow" they said. So I did. And I got a hat with a brim. You know, those shiny, black brims. And I thought that was really grand. I walked around looking at myself in shop windows everywhere; I thought I looked great with that hat. I walked around with the mail, you know; a mailman. 
NARRATOR: $\quad$ Today he sends his own letters.

HARALD: $\quad$ I have written to the dailies Dagbladet and VG, to TV2. But I get no replies.

NARRATOR: $\quad$ One night he watches a physicist on tv. Andreas Wahl talks about stars, about the energy that is out there in space.

HARALD:

He looked very likeable. So I got the idea to enquire whether he would come and have a look at this stuff.

NARRATOR: Harald invites him to the flat in Tveita.

HARALD: $\quad$ That's what I wanted, that he should check my theory. You know, do the same as I had and get the same result. That's what I wanted him to do. But he didn't have time to spare.

JOURNALIST: $\quad$ He'd very much like a scientist to come and look into his invention and test it.

BORGHILD: $\quad$ Do you think there's any point in that? I don't know...

JOURNALIST: $\quad$ What if a scientist looks at it and finds it useless...?

BORGHILD: $\quad$ Yes, do you think he'll be sad if they find out it's useless? Perhaps that will be a blow, I don't know? He believes so much in that stuff, you know. I don't understand it; there's no one else, just him.

Telephone call up 
JOURNALIST: (on the phone) Am I speaking with physicist Andreas Wahl?

ANDREAS WAHL: $\quad$ (on the phone) That's right.

JOURNALIST: $\quad$ I'm calling about a Mr. Harald Brobakken who is an inventor.

ANDREAS WAHL: Right. I think he has sent me some e-mails. I remember he described some battery gizmos he's made.

JOURNALIST: $\quad$ Do you think you might have an inclination and opportunity to join me and visit him some day, next week, perhaps?

ANDREAS WAHL: I think you have to find someone who works with electricity and magnetism. For example a clever chap called Bjørn Samset.

Telephone call up

BJØRN SAMSET: (on the phone) Yes, it's Bjørn Samset. The term "fetch energy from cosmos" sounds somewhat vague. I'd rather have something more specific than that. Svein Stølen is a person who wouldn't mind talking to you, I believe.

SVEIN STØLEN: $\quad$ (laughs on the phone) Sorry I'm laughing; I don't mean to be negative. But... There are many overworked people here - luckily - that's how it is in a university.

JOURNALIST: $\quad$ Many thanks for your help. 
SVEIN STØLEN: $\quad$ You're welcome. Bye bye.

Journalist sighs

Balcony door opens

Guitar music

NARRATOR: $\quad$ They sit on the balcony all three of them. Harald has produced his guitar.

Guitar music and humming

HARALD: $\quad$ (sings:) "And that was all he did!"

Thanks for having me.

Laughter

HARALD: $\quad$ It's 20 years since I used to play, you know.

KJETIL: $\quad$ Yes.

Balcony door closes

BORGHILD: $\quad$ Now you've chatted a lot, pa.

HARALD: $\quad$ Yes, I feel it in my mouth. I'm not quite like I'm supposed to be in my mouth, you know.

KJETIL: $\quad$ No.

HARALD: $\quad$ Oh yes, there are lots of interesting things in the Universe. Oy oу оу - oyoy!

KJETIL: $\quad$ That's why I really hope that if a chemist shows up he will find there is something in this. I really hope, with all my 
heart, that he can sit there with a smile on his lips and really believe "now I have achieved something". I feel this is the chance he needs. If anything should come out of this, it has to happen now.

Telephone call up

OLA NILSEN: $\quad$ (on the phone) Ola Nilsen.

JOURNALIST: $\quad$ (on the phone) I'm calling about a Mr. Harald Brobakken who is an 86 years old man living in Tveita.

OLA NILSEN: In Tveita? That's quite close to where I'm situated. Well, I do know a few things about batteries, I would say.

JOURNALIST: $\quad$ If you are close to Tveita, would you mind dropping by one day and take a look at it?

OLA NILSEN: $\quad$ Yes, I might well do that.

JOURNALIST: $\quad$ Yes yes yes!

OLA NILSEN: When? How pressed are you for time?

Music

Voices

NARRATOR:

The low afternoon sun fills the balcony. Soon the stars will be visible. The chemist is on his way. In the study the lightbulb glows as usual. One wire goes to some small plastic cups filled with a "soup" of zinc, copper and iron. Another to a metal plate the cups are sitting on. In a 
second circuit Harald has connected an ordinary battery which is not being drained of power. The question is where the energy that powers the lightbulbs comes from. And how it moves around.

HARALD:

That's all I want an answer to.

KJETIL:

Yes.

HARALD: And if it doesn't come from the battery, where does it come from? Then we get that to wonder about.

KJETIL: Mm. I'm looking forward to finally getting an answer. We have waited an incredibly long time for this. Right, grandma?

BORGHILD: (laughs) I just hope we get an end to this, sort of. That we get to know a little bit.

HARALD: If this gets recognised it would surely be sufficient to get the physics prize. And then we'd have to go to Stockholm.

BORGHILD: Pa! Don't talk like that. I think that' so... ooh.

HARALD: $\quad$ Well, it might be stupid to say it, but...

BORGHILD: $\quad$ Yes, I think it's so stupid I can't stand hearing it.

HARALD: Well, but it's true.

BORGHILD: $\quad$ Please.

KJETIL: $\quad$ Do you think you will give in if it...? 
HARALD:

BORGHILD:

KJETIL:

HARALD:

KJETIL:

Doorbell

BORGHILD:

KJETIL:

BORGHILD:

HARALD:

KJETIL:

Rummaging

Door opens

KJETIL:

OLA NILSEN:

KJETIL:
Yes, I'll give in.

That's good.

This will be the end of it?

This will be the final.

Then this is extra exciting, then. We'd better cross our fingers.

There he is. Will you open, Kjetil?

Yes.

Pa, you'd better...

Yes, I'm on my way.

You take this and I'll open. (in the entry phone:) Hello? Hi! 
HARALD:

OLA NILSEN:

Rummaging

OLA NILSEN:

HARALD:

OLA NILSEN:

KJETIL:

HARALD:

OLA NILSEN:

HARALD:

OLA NILSEN:

HARALD:
Hello. Harald Brobakken.

Ola. Good to meet you. I'll just get rid of my bag and baggage.

Look here. Brilliant. I must say this is a really nice home lab.

Yes, it is home-made.

Well, home lab too, as I call it.

Home laboratory.

The power that makes the lamps shine, does it come from the battery or not? That's my only question.

For that, we have to check the wires.

Yes. Do you find a way the current could take from the battery to the lamps?

The chemist stoops over the invention on the workbench. Harald and Kjetil pay attention from both sides.

I just need some time to get these wires...

Well, it doesn't matter if you destroy it because this is the end. 
OLA NILSEN: $\quad$ The end? That sounds very dramatic.

NARRATOR: The chemist studies the small plastic cups on the metal plate.

OLA NILSEN: Okay.

NARRATOR: $\quad$ Some of the mixture of elements has run over the edge and down the outside of a cup.

OLA NILSEN: $\quad$ Okay. So there is connection at least at the underside of... No. Where is there a connection underneath?

KJETIL: $\quad$ On that side...

HARALD: $\quad$ There's no connection there. That's exactly the point, that there is no connection. They just sit on the plate.

OLA NILSEN: Then why do I have a light?

NARRATOR: The chemist measures the battery's voltage. Then he stands still for a while, thinking. Harald and Kjetil glance at each other. Outside the stars have appeared. The chemist leans forward again and lifts the plastic cups from the metal plate.

OLA NILSEN: Hm.

NARRATOR: For the first time in several months the light goes out.

OLA NILSEN: If the battery is necessary the power comes from the battery. But what I... 
HARALD: But where does it go?

OLA NILSEN: $\quad$ Yes, where does it go? At least it happens through the plate, through your system. So one place or another you have a conductor that runs through this. It means that the humidity around these containers of yours is so high it conducts the ampere necessary. Because this is a cell. You have created a cell.

I think your answer lies there.

HARALD:

Yes.

NARRATOR:

The chemist thinks that instead of an everlasting battery Harald has made an ordinary battery.

OLA NILSEN: $\quad$ Take some copper pipes you have left over, some nails and connect them and suddenly you have something running.

KJETIL: $\quad$ This is like a nature science project.

OLA NILSEN: $\quad$ Yep. That's it. That's exactly what it is.

NARRATOR: $\quad$ Harald sinks into his armchair. Through the window he dimly sees the stars.

OLA NILSEN: $\quad$ So it may take a while before you get an international breakthrough. But personal breakthroughs are not to despise either.

HARALD:

Yes, yes. Well, thank you very much. I sort of got my eyes opened, you might say. I guess we can conclude this is the end of my career as an amateur physicist. 
OLA NILSEN: $\quad$ No, why would you quit now? Now you have learned a bit so you can continue your work.

HARALD: Well-well-well, we'll see.

OLA NILSEN: Well, thank you for showing me.

HARALD: $\quad$ I want to thank you for taking time to visit;

very kind of you.

OLA NILSEN: $\quad$ Oh, you're welcome. And good luck further on.

HARALD: $\quad$ Well, thanks.

Door opens

KJETIL: $\quad$ Bye bye.

OLA NILSEN: $\quad$ Bye bye.

Door closes

KJETIL: Well, then we got an answer.

HARALD: Yes, I must say we got a straightforward answer.

BORGHILD: (from another room:) How did it go?

HARALD: I don't quite agree with him, though, but so be it. Still, I think I'll give in now.

KJETIL: If he doesn't pack this stuff away before he dies it will 
become a very, very strong memento of him. Because this is... these are his last days, I almost said. For instance, if the lights still are on when he dies I'll let them stay on for as long as possible. And it will be really exciting to see how long they'll keep. Suddenly I'm 50 years old and they're still glowing. So they won't be chucked.

\section{Music}

NARRATOR:

Two days after the visit an e-mail from Harald arrives.

HARALD:

(e-mail:) Hello Sindre. I just want to tell you I didn't agree with the explanation the chemist presented. Among other things, he said it was humidity that transferred electricity from the battery to the lamps. I have known about the humidity for a long time and I believe I have solved that problem. I'd like to hear an expert give an explanation of how this can take place and I welcome the chemist back again.

BORGHILD: $\quad$ You never give in, Harald.

HARALD: I just want an explanation, that's all.

BORGHILD: $\quad$ Do you need an explanation for everything?

HARALD: I would really like to find an explanation of why the lamps still are glowing, you know. When I can prove there is no connection between plus and minus the power must come from elsewhere. And the only place that could be, is cosmos.

Music out 